Journal Home Page:

http://perlinguam.journals.ac.za

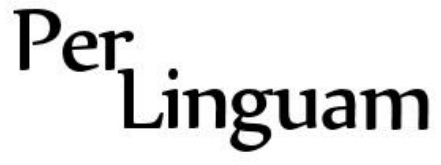

A Journal for Language Learning Tydskrif vir Taalaanleer

\title{
TEACHING GERMAN AS A FOREIGN LANGUAGE IN A MULTILINGUAL SOUTH AFRICAN CONTEXT ${ }^{1}$
}

Anne Baker

University of Johannesburg

Arguments for the promotion of indigenous languages should not be used as reasons against teaching German in a multilingual South African context. Elevating the status of the indigenous languages can go hand in hand with continuing to teach German as a foreign language. This article argues that teachers of German as a foreign language could valuably affirm African languages in their classrooms. The article demonstrates the importance of taking cognizance of the learners' first language in learning a foreign language. Knowing what to emphasise and which elements in the primary language are useful for more effective language learning to take place can be problematic for the teacher who is not familiar with the primary language of the learners. An error analysis of the written work of grade 10 and grade 12 learners of German as a foreign language provides valuable insights for teachers in South Africa who find that their classes are increasingly multilingual. It also suggests ways of providing opportunities to affirm African languages in the foreign language classroom.

\section{Keywords}

foreign language learning; error analysis; multilingualism; African languages; German; contrastive analysis;

\section{FOREIGN VERSUS INDIGENOUS LANGUAGES}

It seems teaching German as a foreign language in the South African context is not generally viewed as important. Ever fewer schools offer German as a subject and young people do not see a future for themselves in teaching or even studying German, nor are they aware of the excellent opportunities knowledge of this subject could offer. At present Germany is one of South Africa's biggest trading partners and 450 German-owned companies in South Africa employ about 65000 people (BuaNews, 2003). This seems to offer a good reason for retaining and even promoting German as a foreign language in our school curriculum.

One could argue that enhancing the status of the indigenous languages by teaching them as school and university subjects is more important in the South African context than teaching foreign languages. It is undeniably true that these languages have been marginalised and stigmatised. However that should not mean that foreign languages should now be marginalised or 
phased out of the school curriculum. Such thinking is short sighted and does not take into account the value knowledge of foreign languages has in the global village we are living in. The solution to this problem is not simple, because the South African linguistic situation is very complex, as Webb (2002) has so ably described.

\section{RELATIVE LANGUAGE STATUS}

Part of the solution to the seeming impasse seems to lie in elevating the status of the indigenous African languages rather than in reducing the number of languages learners may elect to do at schools. At present, the primary languages of the majority of the South African population are being significantly marginalised in education or treated as minority languages because of lack of status and economic importance (see Kamwangamalu, 1995; Mawasha, 1996). Even in the eyes of the speakers of these languages themselves, English is the language of choice in education, because it is considered to be the gateway to success. According to Mawasha: 'To be educated and trained means having acquired knowledge and expertise mainly through the medium of English' (Webb, 2002:12). Professor C.T. Msimang, professor of Zulu at the University of South Africa makes a much stronger statement: 'Most black people in South Africa have come to hate their languages and consider them irrelevant in the education process' (Webb, 2002:12).

What many people fail to recognise, is that the development of cognitive abilities takes place in the primary language and is transferred to other languages at a later stage in the child's development. According to a statistical analysis of the current situation in our schools $70 \%$ of the learners with an African language as primary language only have basic interpersonal communication skills (BICS) in English as opposed to cognitive academic language proficiency (CALP). They lag behind their (English L1) classmates, because they have not developed sufficiently on a cognitive level before being subjected to being taught in English (Webb, 2002). Research results produced in KwaZulu-Natal in 1986 (Odendaal, 1986 cited in Webb, 2002) show that learners in grade 5 could not understand questions such as: 'Where is your home?' and: 'In what standard are you?'. $83.5 \%$ of the teachers indicated that their learners did not understand their textbooks. In a questionnaire distributed in Northern Province in 1996 (Webb, 2002:11), it was established that only $5 \%$ of the teachers who would be teaching through medium of English had adequate command of the language. This situation will have to change and the Department of Education has to find a way of improving mother tongue, or primary language education in South Africa if the problem of subtractive multilingualism is to be addressed.

Skutnabb-Kangas (1988) cites several examples of groups of people whose primary languages do not enjoy high status in the community and who fail to learn the high status languages well. In research carried out in 1988 she gives a number of reasons for this phenomenon, including low language status of the primary language. In contrast she cites programmes that lead to additive bilingualism, such as the immersion programmes in Canada, where the English speaking majority are taught in a high status language, French, and achieve a high measure of additive bilingualism. The L1 of these learners has high status, they study the language voluntarily, they are taught by bilingual, well qualified teachers, they are self motivated, their L1 as well as the L2 are taught in the school on a high level and they have many opportunities of using the L1 on a high level in 
formal situations outside of school. All these factors are the result of the high status of their L1, English.

The situation in South Africa is, of course not the same as in Canada, nor can it be. English as a world language can not be compared to the many indigenous South African languages that have only limited usefulness inside the borders and no usefulness outside the borders of SA. The stigmatisation of these languages under apartheid is still felt, even though theoretically all the official languages have equal status. Even in the black community some languages have higher status than others. See for instance the position of Venda in the Pretoria scenario sketched by Webb (2002: $63-64){ }^{2}$

Perceptions, mistrust and stigmatisation are not things that can be changed in a short period of time. Affective aspects of language behaviour should not be under estimated. The parents who are raising children today and who are making decisions concerning their futures are the products of apartheid. They are suspicious of mother-tongue education because it reminds them of African education, an inferior educational system reserved for Black learners during the apartheid years. The prevailing view is that the cost of giving mother tongue education is in any event prohibitive, not to mention an organisational nightmare. In a country in which so many people are unemployed and undernourished, equal language status does not seem quite so important to the man in the street. Heugh (2005a) takes a very different view, arguing that mother tongue education could be cost-effective since it could lower the dropout and repetition rates.

I would argue that if the inherent value of all the indigenous languages were recognised, in the eyes of the general public and more especially by the speakers themselves, more parents would opt to choose the mother tongue as a medium of instruction. Not only would the children acquire the desired level of cognitive development, but the level of learning English would improve (see Heugh, 2005b). That, in turn, could lead to a greater degree of acceptance of other foreign languages, which would include German.

\section{LESS IS NOT ALWAYS MORE}

Webb (2002) contends that language influences the ability to generate income. The general population should be educated and persuaded that mastering the primary language first and on a high level is a prerequisite for mastering subsequent languages, which in turn would improve the ability of their children to generate a better income. As a result, the attitude towards the indigenous languages should be changed for the better in the long run.

Multilingualism should be viewed as an asset rather than as an impediment, and the status of the African languages elevated in the eyes of the speakers themselves. This would have a positive effect on the teaching of indigenous languages as well as foreign languages. Teachers and lecturers of German as a foreign language in South Africa could help PanSALB (The Pan South African Language Board) to fulfil its task by acknowledging the African languages in the foreign language classroom. The German as a foreign language teacher should show the Zulu speaking learners the ways their L1 can improve their acquisition of German and make them realise that their L1 provides them with points of reference that the other learners do not have. Rather than 
considering Zulu to be so different from the Germanic languages that it is irrelevant to the process of learning German, Zulu speaking learners can be shown that their L1 has something to contribute. Affirming Zulu in this way should add to its worth in the eyes of the learners.

\section{ESTABLISHING SPECIFIC FOCAL POINTS}

Not many teachers of German are familiar with any of the African languages. Until now, research into L1 and L2 influence on the acquisition of German as L3 has been limited to studying the influence of Afrikaans and English. Until recently, there have been no comparative studies involving any of the indigenous languages, bar a short phonetic comparison of German and Zulu (Mahlig, 2003). However, a contrastive analysis of German and Zulu is too broad to be of specific use to the German teacher who has no background in African languages. In order to determine useful points of departure for the teacher who teaches German as a foreign language to a linguistically mixed group, an error analysis was carried out on the written work of learners of German. The subjects of this study were from five different schools so that different language backgrounds could be included. For the purposes of this article the spotlight will fall on learners whose primary language is an African language, with other groups functioning as control groups. The contrastive analysis falls outside the scope of this particular article.

\section{ERROR ANALYSIS: A USEFUL TOOL}

Errors are an important source of information about foreign language acquisition, because they can give valuable information about the state of the learner's interlanguage at different stages of language learning. The term 'interlanguage', coined by Selinker (Brown, 1994:203), is used here to indicate a form of the target language which is in a state of flux, changing as the learner acquires more knowledge of the language. The aim of the error analysis in this particular study is to establish the influence of prior language knowledge on the interlanguage of language learners with an African L1 for didactic purposes. The focus is on written production as opposed to oral production and reception.

Even though error analysis has its limitations, it can be a useful tool to narrow down specific problem areas. As Ringbom (1987:160) points out, the negative signs of cross linguistic input are the only tangible ones. Positive influence may be assumed, but the exact extent of it cannot be accurately and objectively assessed, because the researcher has to rely on the self-assessment of the learner (Mißler, 1999:79-102). The error analysis carried out in this particular study takes cognisance of the influence of African language L1 as well as L2 and L3 influence on the Lx, German. It should be noted that not all errors impede communication and that L1 borrowing is not the only source of errors. Furthermore, in order for the language instructor to determine what strategy to employ in teaching German to specific groups of learners, she/he must know that a specific utterance is erroneous, why the utterance is erroneous, which category the error belongs to, what may have caused the learner to make the error and how serious it is.

The fact that interlingual errors are the main focus of this study determines which errors are analysed and explained. It is hoped that it provides teachers with important insights at the same time. Even though the African languages are not taught as L1 at many schools yet, African 
speaking learners could benefit from undertaking their own comparisons guided by the teacher, even if only on an affective level.

\section{LANGUAGE FACTORS}

In this particular study the Zulu speaking participants' knowledge of Afrikaans and English was also taken into consideration, because all prior knowledge is important for the acquisition of new knowledge. In this instance, the language acquisition strategies the learners employed in acquiring two other Germanic languages, Afrikaans and English, in a formal setting (i.e. at school) as well as the specific linguistic knowledge of these two languages come into play especially. Evidence presented in recent research shows the influence of L2 learning on all subsequent language learning. Hufeisen (1998:171) distinguishes between L1 acquisition and L2, L3 and Lx learning and points out that the language learning experience of L3 and Lx learners is an additional factor in the whole process of language learning, even though a subsequent study (Gibson, Hufeisen and Libben, 2001) shows that the TL being L4 rather than L3 or L2 does not necessarily constitute an advantage, but could bring about greater confusion. Köberle (1998:93ff) points out several advantages of a language teaching method that makes use of the prior language learning experience of the $\mathrm{Lx}$ learner. She refers to this teaching method as the 'interaktionsfokussierende Methode', which includes both negative and positive transfer. She contends that this is more motivating than focussing on negative transfer only, especially at the beginning. One advantage of using L2/L3 knowledge in Lx learning is the fact that most Lx learners have little or no knowledge of the language system of their L1, but have at least some knowledge of the language systems of subsequent languages. This could hold true in the South African situation, where the L1 is often not taught as an L1 at schools.

\section{THE PARTICIPANTS}

The participants were drawn from five different schools, namely the Deutsche Internationale Schule Johannesburg (30 learners), the Deutsche Schule Pretoria (12 learners), Rand Park High School (5 learners), Ogwini High School (15 learners) and Linden Hoërskool (17 learners). The groups from Linden Hoërskool, consisting of 17 learners from an Afrikaans speaking background and from Ogwini High School, consisting of 15 learners from a Zulu speaking background were the most homogeneous groups. They had all learned English in a formal setting and were in grade 12. Two of the learners from Linden Hoërskool had one German-speaking parent. The selected learners from the Deutsche Schule Pretoria were all from a Zulu speaking background and had learned English and Afrikaans in a formal setting. Six of these learners were in grade eight, three were in grade ten and three were in grade 12. The group from the Deutsche Internationale Schule Johannesburg consisted of eight learners whose L1 is an African language, six learners who indicated both Afrikaans and English as L1 and 16 whose L1 was English. Eleven of these 30 learners were in grade 12, the rest were in grade ten. Four of the five learners from Rand Park High were from an African language background and one was of Chinese descent. All of them had learned Afrikaans and English in a formal setting. They were all in grade 12. The learners from the two German schools started learning German in grade six, as opposed to the learners from the other three schools, who started in grade eight. For this reason, younger learners from the German schools were also included in the study, since after five years of learning German 
they could be expected to be on a par with those who started only in grade eight. For all participants German is at least L3.

The following table gives an overview of the participants according to school, grade and L1. In the case of learners whose L1 is an African language, no real difference has been found in the error analysis which would necessitate a distinction between the Nguni and Sotho languages. For this reason, the term 'African' (language) was chosen for use where the group was mixed.

Table 1: Overview of participants according to school

\begin{tabular}{|c|c|c|c|c|}
\hline School & Grade & $L 1$ & Number & Total \\
\hline \multirow[t]{6}{*}{ Deutsche Schule JHB } & 10 & African language & 4 & \multirow[b]{3}{*}{19} \\
\hline & 10 & Eng. /Afr. & 5 & \\
\hline & 10 & Eng. & 10 & \\
\hline & 12 & African & 4 & \multirow[b]{3}{*}{11} \\
\hline & 12 & Eng. /Afr. & 1 & \\
\hline & 12 & Eng. & 6 & \\
\hline \multirow[t]{3}{*}{ Deutsche Schule PTA } & 8 & Zulu & 6 & \multirow[b]{3}{*}{12} \\
\hline & 10 & Zulu & 3 & \\
\hline & 12 & Zulu & 3 & \\
\hline \multirow[t]{2}{*}{ Linden Hoërskool } & 12 & Afrikaans & 15 & \multirow[b]{3}{*}{17} \\
\hline & 12 & Afr./German & 2 & \\
\hline \multirow[t]{2}{*}{ Rand Park High } & 12 & African & 4 & \\
\hline & 12 & Chinese & 1 & 5 \\
\hline Ogwini & 12 & Zulu & 15 & 15 \\
\hline
\end{tabular}

The work done by learners from Ogwini High School consisted of creative writing only, because that was the only material that was made available. Another factor that makes this group unique is the fact that their L1, Zulu, is taught as a subject and they can choose between German and Afrikaans. This means that there is almost no Afrikaans influence in their work, but very extensive English influence. Some of them seem to have written their essays in English and subsequently translated them into German. The work of these learners will be discussed separately, except for those errors that they have in common with the other learners.

\section{DATA USED FOR ERROR ANALYSIS}

The matric portfolio of the grade 12 learners of 2002 from the two German schools, Rand Park High and Linden Hoërskool, formed the basis for the error analysis carried out on their work. The material consisted of essays on literary topics (DSJ grade12) as well as creative writing, dictation and comprehension work.

Creative writing, comprehension work and dictation exercises by the younger participants (grade 10) from the German schools were also analysed. The advantage of independent writing over grammar exercises is that independent writing is a better test of real linguistic knowledge. This became evident in candidates' performance on material Steyn (1990) used to test the usage of 
reflexive verbs. The grammar exercise involved tested only the correctness of the form and position of the reflexive pronoun in a grammar exercise. The candidates knew that a reflexive pronoun was required, but some of them inserted it in the wrong place. Because the distribution of reflexive verbs in German differs from English, Afrikaans and Zulu it is also important to test whether the candidates know when to employ the reflexive in German. The creative writing provided by all the participating schools showed clearly that the candidates are often unaware that it is required. Consider the following examples:

Bingo und Stefan sind gesetzen instead of Bingo und Stefan haben sich gesetzt.

...während, Ronny, Karel's Vati, ausziehen instead of ...während Ronny sich auszieht.

\section{GENERAL TRENDS}

In spite of dissimilarities regarding age, tasks, L1 and the size of the groups, some general trends could be observed from the elicited data.

\section{The definite and indefinite article}

All the participants have difficulty with the German noun classification system, i.e. using the correct article and adjective endings. The Afrikaans speaking learners seemed to perform better than the others, perhaps an indication that perceived (and real) linguistic similarity lightens the burden sufficiently to facilitate acquisition. The sample was taken from grade 12 learners from the Afrikaans and English high schools and from grade 10 learners from the German schools, because these particular groups have all had five years exposure to German instruction. Of 17 Afrikaans speaking learners, $70.58 \%$ had above $60 \%$ correct usage of the article in German. Of 13 English mother tongue speakers, 15\% (2 learners) had above 60\% correct usage, and of 11 learners from an African language background $47.5 \%$ had above $60 \%$ correct usage of the article. Of the English speaking learners, $77 \%$ had less than $50 \%$ correct usage of the article, one of whom only managed $6 \%$ correct usage. See Table 2 for a more detailed exposition.

Table 2: Correct usage of the definite article in German according to L1

\begin{tabular}{|l|l|l|l|}
\hline $\begin{array}{l}\text { Correct usage } \\
(\%)\end{array}$ & Afrikaans L1 & African L1 & English L1 \\
\hline $80 \%-95 \%$ & $35.3 \%$ & $0 \%$ & $0 \%$ \\
\hline $70 \%-79 \%$ & $17.64 \%$ & $40 \%$ & $15 \%$ \\
\hline $60 \%-69 \%$ & $17.64 \%$ & $7.5 \%$ & $0 \%$ \\
\hline $50 \%-59 \%$ & $23.53 \%$ & $45 \%$ & $8 \%$ \\
\hline Below 50\% & $5.89 \%$ & $7.5 \%$ & $77 \%$ \\
\hline
\end{tabular}

The data might suggest that the Zulu language system of word classification and congruence may have made a difference in the acquisition of the German system by the participants from an African language background. They were in the same class as the English speaking learners. This means that teaching method does not account for the difference between the African language L1 speakers and the English L1 speakers. It would be useful to try using the similarities between German and Zulu and heightening the linguistic awareness of the African speaking learners in the 
area of noun classification in order to test if it could further facilitate acquisition. The fact that this aspect of language learning falls into the general encyclopaedic category and can therefore be committed to memory by rote learning by each individual learner should have cognitive benefits. In the affective domain one hopes that taking cognisance of the learner's mother tongue, thus enhancing its status by acknowledging its potential usefulness in acquiring the TL could diminish the emotional distance to German language and culture and further improve acquisition. The language learning experience of these learners, who have already learned two other Germanic languages (English and Afrikaans) in a formal context, may also have contributed to their success.

The position of the learners from Ogwini High School is quite different from that of the African L1 speakers in the German schools. Of the 15 participants none achieved $70 \%$ or more correct article usage, 20\% (3 learners) achieved between 60\% and 69\%, 26\% (4 learners) achieved between $50 \%$ and 59\%, $40 \%$ (6 learners) achieved between $40 \%$ and $49 \%$ and the remaining $14 \%$ (2 learners) achieved less than $34 \%$ correct usage, as illustrated in Table 3.

\section{Table 3: Correct usage of the German definite article by Ogwini High School learners}

\begin{tabular}{|l|l|}
\hline Correct usage (\%) & Zulu L1 \\
\hline $70 \%-100 \%$ & $0 \%$ \\
\hline $60 \%-69 \%$ & $20 \% /$ \\
\hline $50 \%-59 \%$ & $26 \%$ \\
\hline $40 \%-49 \%$ & $40 \%$ \\
\hline Below $40 \%$ & $14 \%$ \\
\hline
\end{tabular}

It may be assumed that the teacher's level of German proficiency meant that these learners were not exposed to the correct usage to the same extent as the learners from the German schools. This could be a contributing factor, as could the quality of teaching. Their lack of Afrikaans knowledge could also cause them to perceive German as more foreign than any of the other groups in the study would perceive it, which would make learning more difficult on a cognitive as well as on a psychological level. To many of them, learning German is a means to an end. They express ideals of studying medicine or other high status professions and then practicing in Germany. This instrumental motivation may not be strong enough for them to aspire to a high level of competency in German, but to aim for basic communication skills only, resulting in a low level of accuracy.

Although the size of the sample is not sufficient to make firm generalisations, there is a clearly observable trend. Hufeisen (2003:106) quotes Aronin and ó Laoire (2001) who stress the importance of studying multilinguality in different cultural contexts, which is borne out by the results of this analysis.

Furthermore, the fact that the English speaking participants from the German school in Johannesburg performed so badly compared to learners from an unrelated language background in their class (African languages) as well as learners from a related language background (Afrikaans in Linden) might indicate a higher degree of error acceptance on the part of the English L1 speakers, whose L1 is a majority language in the South African context because of its status (Dyers, 2003:62). These learners could possibly be less motivated to learn the high status 
L3 (German) correctly, because their L1 is also a high status language and may even be perceived to have a higher status than the TL, because of the number of speakers and the economic power of English in the South African context. Potential usefulness of German in the South African context (or lack of it) could also have had a detrimental effect on the motivation of these learners. The Zulu language speakers, whose L1 may be a majority language numerically but is a minority language socially (Dyers, 2003:62), might be more motivated to learn the high status Lx well. The difference between these African L1 learners (DSJ) and the Zulu L1 learners from Ogwini High School could be due to lack of exposure to German L1 speakers at Ogwini, thus impacting on perceived usefulness and opportunities for practice. Another factor could be a social one. The learners from Ogwini live in poverty, whereas the African L1 learners at the German School are likely to be in a better position socially, putting them in a better position to achieve. Due to practical constraints, methodological factors could not be included in the study of the group at Ogwini, but could have contributed to the results. However, the fact that methodological factors could be ruled out in the case of the English speaking learners from DSJ, could also suggest that lack of a high level of competency in Afrikaans could be the common denominator between these two groups. Further study is needed in order to come to a more accurate conclusion.

\section{L1 specific errors}

All the participants have problems with the correct usage of personal pronouns. From the elicited data it would appear that the candidates with Afrikaans and/or English L1 all use es when referring to inanimate objects and animals regardless of the correct article, but always choose the correct personal pronoun when referring to people. The only participants who choose the wrong personal pronoun when referring to people, are those from an African language background. This fact would seem to indicate a specific link to the L1 of these candidates. Compare the following set of examples taken from the writing of students with a European L1 to the examples taken from students with an African L1.

English or Afrikaans as L1

English

die Wand - es; die Katze - es; der Ton - es; die Personifikation - es; der/das Gedicht - es; der Tod - es.

Afrikaans

die Wohnung - es; Max, holt Waldi und bringt es zu mir.

African language as L1

Southern Sotho

- zwei Kätzchen - ihn; die Wand - es; Diese Kätzchen hatten weg von ihren Mutter gegangen, weil sie ihr nicht wollte; Eines Tages verlört sich eines der zwei Kätzchen und Luchs sucht $\underline{i h n}$, aber er kann ihn nicht finden.

- Sie entwirft Mode. Vielleicht macht er auch das Hobby zum Beruf.

- Sie wünscht ihm (instead of sich) ein kleines Haus mit Garten.

- Herr Müller ist sehr besonderig. Sie kann..., aber sie vergessen seinen Autoschlüssels. 


\section{Northern Sotho}

- ...fand sie ein Kuh und sie nennte es Bella...macht ein Stall für es... sie muss Heu für sie und ihr Stall finden. Sie hat viel Angst für Menschen, weil sie fühlte, dass Menschen $\underline{\mathrm{ihn}}$ droht.

- Ein andere Grund warum sie so schlaflosig ist, ist dass sie nicht im freien bewegt kann und es kümmert ihn sehr viel.

- ...weil sie glaubt, dass schmutzige Figuren lenkte ihn von ihr Gedanken ab.

- Ludwig Uhland benutzt das Stilmittel, weil es möchte uns beweisen, dass...

- Sie denkt an alle Menschen, die sie gekannt hatte und weißt, das alle dieser Menschen zu ihn gehört bis zu ihrem Tod...

Zulu

- Lisa hat keine Lust, um seine Haare zurecht zu machen. Wenn seine Freundinen seine kritisiert holt sie Modezeitschrift aus.

- Er lässt den Ball fallen, weil sie zu weich ist.

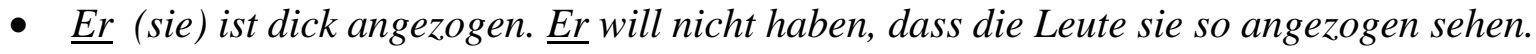

- Sie ist froh, dass niemand $\underline{\text { hhn }}$ so sieht, weil sie schrecklich aussieht.

Even though not all the participants with an African L1 have the problem cited above, none of the writings of candidates with a European L1 contain this particular error, which would indicate a language specific origin. Another reason for such an assumption is the fact that similar errors occur in the Afrikaans and English usage of many speakers with an African language background. The source of this error is to be found in the noun classification system of the languages in question. (See Baker, 2006 for more detail.)

Recognising word boundaries also seems to be more problematic to learners from an African L1 background, which may be linked to the fact that in Zulu one word can represent an entire sentence. Compare the Zulu example to the German translation.

- Usebenzaphi?

(Where do you work?)

- Wo arbeitest du?

Mahlig (2003:14) suggests a link with the phonetic typology of Zulu and recommends exercises to eliminate the problem. She comments as follows:

Der Vokalneueinsatz wird nicht immer realisiert. Zulusprecher neigen dazu, vokalanlautende Silben und Wörter zu binden.

Her recommendation to the teacher is that word boundaries have to be practised particularly. The fact that the errors found in the work of Zulu L1 learners in this particular study do not display a specific link with words starting with a vowel does not necessarily invalidate her assertion. The degree of insecurity they display compared to learners from other language backgrounds does indicate a link with their L1. The following examples were taken from the work of students with an African language background. Most of these errors occurred in the work of grade 10 learners, 
which seems to indicate that the problem is overcome over time, maybe because dictation forms part of the teaching activities. Consider the following examples:

- Meine Familie besteht aus sechsmitgliedern (sechs Mitgliedern); (RPH grade 12, L1 Sotho);

- Wo bleibt da der eigenestiell (der eigene Stil), die eigenemeinung? (eigene Meinung) (DSJ grade 10, several candidates, variety of L1 e.g. Tswana, English/Afrikaans, English, examples taken from a dictation exercise);

- Es hat wie in einem Bilder buchausgesehen (Bilderbuch ausgesehen). (DSP grade 8, L1 Zulu)

- Zuweich (zu weich); ausbetong (aus Beton); viermeter (vier Meter); mit einem einzigenschlag (einzigen Schlag); vör ein paarmark (für ein paar Mark); es ist nicht zuleicht (zu leicht); brauchen einigezeit (einige Zeit); fertigwerden (fertig werden); zehnterstenmahl (zum ersten Mal); (DSP grade $10 \mathrm{L1}$ Zulu);

- Sichbesinnte (besinnt sich) auf den Beruf; zuerste Mal (zum ersten Mal); einbißchen (ein bisschen); es solltekein (sollte kein) Wunder sein; ausbetong (aus Beton). (DSP grade 10, L1 Zulu);

- Kristlichengemeinde (christlichen Gemeinde); im Sozialenbereich (sozialen Bereich); wie man Wunde bessermache (besser macht) (DSP grade 10, L1 Zulu);

- Mit dem kleinenball (kleinen Ball); inder (in der) Küche (DSP grade 8, L1 Zulu);

The fact that this phenomenon occurs more in the corpora taken from learners from the German schools could be because they are exposed to mother tongue speakers of German and are learning in a German speaking environment with more aural exposure rather than written exposure to German. The dictation task lends itself more to this kind of error, which could account for the number of errors made by the grade 10 learners from the DSJ in a dictation. Since this particular error was made by more learners with a Zulu language L1, however, it could still indicate a link with Zulu.

Elements found in Black South African English occurred in the German of some of the black learners. Examples of such elements are as follows:

A few examples of appositive usage of pronouns are:

- Er sagt, dass die Kinder ihrer Eltern $\underline{\mathrm{ihr}}$ danken sollen.

- Es wurde es ihm nicht klar.

- Es wird es ihr klar...

- Dieser Satz is eine Metapher und bedeutet, dass die Menschen oft ihr Städten aufbauen und nicht es die Städten nicht zerstören.

- Jenseits des Flusses erwarten sie uns viele Gefahren.

- Für meine Tante gebe ich $\underline{\text { Sie }}$ R5 000 jeden Monaten.

Two examples of what could be called 'mixing the senses' were found in the work of two learners with an African L1. 
- Ich mag mit ihr ein Hotelzimmer zu teilen. Es schmenckt sehr schön!

- Wir wissen, dass die Sänger gut singen, weil der Klang zum Ohre sehr schön blickt...

Using the indefinite article where it should be omitted is another error that occurs in the English of Zulu L1 speakers and which is transferred into German.

- Sie bringen ein Kleider vor uns zu anziehen.

- Einen Disciplin, ich habe Disciplin nicht weil ich gehorchen eine lehrer bin.

- Viele Ländern hat ein probleme mit Ausländer.

Even though using the wrong preposition is an error that occurs in the work of all the candidates, a few examples of particularly unusual prepositions were found in the work of Zulu L1 learners. This is probably due to the fact that African languages do not have prepositions.

- Sie müssen nach ihre Kinder denken.

- Ihr müsst bei Süd-Afrika kommen.

- Nach meinem Schulabscluß möchte ich nach Wits studiere.

Using andere...andere instead of einige...andere.

- Andere Bälle sind hart und andere Bälle sind weich.

\section{DEGREE OF DISTURBANCE CAUSED BY THE ERRORS}

The greatest degree of disturbance is caused by errors relating to semantics, and to some extent orthographical errors which result in words taking on a different semantic value. Some examples of errors that cause misunderstanding are the following:

- Wrong personal pronoun e.g. Sie ist froh, dass niemand ihn (instead of sie) so sieht.

- Misspelt words that result in existing words with another meaning e.g. Lehre (teaching) for Lehrer (teacher).

- False friends e.g. halb eins for half past one; spenden/spendieren for ausgeben.

\section{CONCLUSION}

Teachers of German as a foreign language could make a small but telling contribution to promoting the notion that multilingualism as an asset. Even though contrastive analysis is not the panacea it was once thought to be (Brown, 1994), it still remains true that language learners look for differences and similarities between the target language (TL) and the other languages in their repertoire (Baker 2005). If German-as-a-foreign-language teachers could promote this in their classroom and it could even spill over into the other language classrooms, a number of advantages could accrue. Linking existing knowledge with new knowledge is an accepted pedagogical principle (Brown, 1994; Baker, 2005). If common phenomena are emphasised in the 
teaching situation and the learners themselves are encouraged to find such similarities in their primary languages, it could elevate the status of their primary language, not only in their own eyes, but also in the eyes of their class-mates. At the very least it would generate interest on the part of the learners, not only for the foreign language, but also for their own. Goethe's maxim that those who do not know other languages also know nothing about their own comes to mind here.

One of the practical results of such an interlingual approach could be a regional text-book for teaching German as a foreign language in SA, which not only considers Afrikaans and English, but includes Zulu as well. As good as the books are that come to us from Germany and other reputable publishers of teaching materials, none of them take the South African language constellation into consideration, nor can they do so. It is up to South African researchers to develop suitable teaching materials and do the necessary research that has to precede such a venture, e.g. comparative analyses such as the one referred to (Baker 2006) with respect to German and Zulu. The text book series developed by Skorge, Chubb, Rode and Du Toit (1987) has made a significant contribution; it would be wiser to augment it than to invent the wheel all over again.

African languages should become a compulsory part of the curriculum, especially, but not only for non-African language speaking education students.

\section{END NOTES}

${ }^{1}$ This article draws on a doctoral thesis submitted in 2006

${ }^{2}$ Webb describes a situation where Venda speaking children change their names into Pedi names, because they are ashamed of their Venda heritage and want to fit into the Mamelodi environment, which is predominantly Pedi.

\section{REFERENCES}

ARONIN, L \& M ÓLAOIRE. 2001. Exploring multilingualism in cultural contexts: Towards a notion of multilinguality. Sektionsvortrag auf der Third International Conference on Third Language Acquisition. September 2001. Leeuwarden, NL.

BAKER, A. 2005. Noun classification and congruence in German and Zulu - a contrastive analysis. In: Journal for Language Teaching, 39(1): 1-16.

BAKER, J. 2006. Teaching German as a foreign language with specific reference to Zuluspeaking learners. Unpublished doctoral thesis. University of Johannesburg.

BROWN, HD. 1994. Principles of language learning and teaching. Third edition. Englewood Cliffs, NJ: Prentice Hall Regents.

BuaNews 2003. No author. SA, Germany strengthen ties. http://www.southafricainfo/pls/procs/ iac.page. [12 May 2006]. 
CORDER, SP. 1981. Error analysis and interlanguage. Oxford University Press.

DYERS, C. 2003. Intervention and language attitudes: the effects of one development programme on the language attitudes of primary school educators. Journal for Language Teaching, 37(1): 60-73.

GIBSON, M, B HUFEISEN, \& G LIBBEN. 2001. Learners of German as an L3 and their production of German prepositional verbs. In Cenoz, J, B Hufeisen \& U Jessner (Eds), 2001. Cross-linguistic influence in third language acquisition: Psycholinguistic perspectives. Clevedon: Multilingual Matters.138-145.

HEUGH, K.2005a. Language education models in Africa: Research, design, decision-making, outcomes and costs. Draft chapter for a report entitled Optimising learning and education in Africa: The language factor commissioned by ADEA, GTZ, Commonwealth Secretariat.

HEUGH, K. 2005b. Mother tongue is best. HSRC Review, 3(3):6-7.

HUFEISEN, B. 1993. Fehleranalyse: Englisch als L2 und Deutsch als L3. In: IRAL, 31(3): 242256.

HUFEISEN, B. 1998. L3 - Stand der Forschung - was bleibt zu tun? In Hufeisen, B, und B Lindemann (Hrsg.), Tertiärsprachen. Theorien, Modelle, Methoden. Tübingen: Stauffenburg. $169-183$.

HUFEISEN, B. 2003. L1, L2, L3, L4, Lx - alle gleich? Linguistische, lernerinterne und lernerexterne Faktoren in Modellen zum multiplen Spracherwerb. In Baumgarten, N, C Böttger, M Motz \& J Probst (Eds), Übersetzen, Interkulturelle Kommunikation, Spracherwerb und Sprachvermittlung - das Leben mit mehreren Sprachen. Festschrift für Juliane House zum 60. Geburtstag. In: Zeitschrift für Interkulturellen Fremdsprachenunterricht [Online], 8 (2/3), 97 - 109.

KAMWANGAMALU, N. 1995. English in language planning in the new South Africa. In Le Roux, C (Ed.), Constitutionally enshrined multilingualism: Challenges and responses. Proceedings of the $15^{\text {th }}$ Annual Conference of the Southern African Applied Linguistics Association, 10-12 July, University of Stellenbosch.85-107.

KÖBERLE, B. 1998. Positive Interaktion zwischen L2, L3 und L4 und ihre Applikabilität im Fremdsprachenunterricht. In Hufeisen, B und Lindemann, B (Hrsg.), Tertiärsprachen. Theorien, Modelle, Methoden. Tübingen: Stauffenburg.89-109.

MAWASHA, A. 1996. Sample views of African post-graduate students regarding English and the African languages as media of education in African schools in South Africa. Per Linguam, 12(1):15-23. 
MAHLIG, M. 2003. Zulu. In Hirschfeld, U (Ed.), Phonetik international: von Afrikaans bis Zulu; kontrastive Studien für Deutsch als Fremdsprache. http://www.heidrun-popp.de. [August 2004].

MIßLER, B. 1999. Fremdsprachenlernerfahrungen und Lernstrategien. Eine empirische Untersuchung. Tübingen: Stauffenburg Verlag.

RINGBOM, H. 1987. The role of the first language in foreign language learning. Clevedon: Multilingual Matters.

SKORGE, S, K CHUBB, R RODE \& R DU TOIT. 1987 Deutsch ZA. Cape Town: Maskew Millar Longman.

SKUTNABB-KANGAS, T. 1988. Multilingualism and the education of minority children. In Skutnabb-Kangas, T \& J Cummins (Eds), Minority education: From shame to struggle. Clevedon: Multilingual Matters.9-44.

SRIDHAR, SN. 1981. Contrastive Analysis and Interlanguage. Fisiak, J, Contrastive analysis and the language teacher. Oxford: Pergamon Press.207-41.

STEYN, EC. 1990. Verzögerungsmomente im deutschen Satzbau. Unpublished master's dissertation, Rand Afrikaans University.

WEBB, V. 2002. Language in South Africa. The role of language in national transformation, reconstruction and development. Amsterdam / Philadelphia: John Benjamins Publishing Company.

\section{BIOGRAPHIC NOTE}

Anne Baker lectures in German as a foreign language at the University of Johannesburg, and is currently involved in further research at Ogwini High School. Email: abaker@uj.ac.za 